\title{
ВПЛИВ ІШЕМІЧНО-РЕПЕРФУЗІЙНОГО СИНДРОМУ КІНЦІВОК НА ВІДХИЛЕННЯ ПОКАЗНИКІВ ЦИТОЛІТИЧНОГО СИНДРОМУ
}

\author{
Державний заклад «Український науково-практичний центр екстреної медичної допомоги \\ та медицини катастроф МОЗ України», Київ
}

РЕЗЮМЕ. В останні роки в Україні, як і у всьому світі, зростає кількість надзвичайних ситуацій як природного, так і техногенного характеру. Особливе місце серед надзвичайних ситуацій займають терористичні акти, навмисне та ненавмисне використання вибухових пристроїв у побуті. Особливістю таких ситуацій $є$ виникнення високоенергетичних пошкоджень, які супроводжуються масивною кровотечею, пошкодженням значного масиву м'яких тканин. Такі випадки потребують особливої уваги клініцистів, оскільки до несприятливих факторів у таких постраждалих додається ішемічно-реперфузійний синдром кінцівок унаслідок накладання кровоспинних джгутів. Його дія при поєднаній травмі фактично не вивчена.

Мета роботи - вивчити вплив ішемічно-реперфузійного синдрому на показники цитолітичного синдрому при травмі органів черевної порожнини, ускладненій гіповолемічним шоком у ранньому післятравматичному періоді.

Матеріал і методи. В експерименті використали 80 статевозрілих білих щурів-самців лінії Wistar масою 190220 г, які перебували на стандартному раціоні віварію.

Тварин поділили на контрольну і 3 дослідних групи (по 8 тварин у кожній групі). У тварин першої дослідної групи під тіопенталонатрієвим знеболюванням (40 мг·кг $)$ проксимально на нижні лапки накладали кровоспинний джгут терміном на 120 хв., що викликало розвиток ішемічно-реперфузійного синдрому. У другій дослідні групі, моделювали закриту травму органів черевної порожнини за допомогою нанесення двох дозованих ударів у область черевної порожнини; шляхом пересічення стегнових судин та кровопускання від 20 до 22 \% об'єму циркулюючої крові в групі моделювали гіповолемічний шок. В третій групі дослідження поєднували пошкодження перших двох груп. Тварин контрольної групи вводили в наркоз, без формування жодних травм.

3 метою визначення змін цитолітичного синдрому визначали активність ферментів - маркерів цитолітичного синдрому АлАТ і АсАТ уніфікованим методом.

Тварин дослідних груп виводили з експерименту в умовах тіопенталонатрієвого наркозу методом тотального кровопускання з серця.

Результати. Наші дослідження виявили, що за умов змодельованих травм, незважаючи на їх тип, розвиваються цитолітичні процеси, які мають системний характер. Так, уже через 1 добу посттравматичного періоду зростає активність АлАТ та АсАТ, яке чітко відмічається не лише в ГД-2 і ГД-3, а і в ГД-1. У подальшому, до 3 доби, процес деструкції клітинних мембран поглиблюється, що проявляється істотним збільшенням активності АлАТ і АсАТ сироватки крові, і продовжує поглиблення до 7 доби. Тенденція до зниження рівнів АсАТ і АлАТ спостерігається лише на 7 добу у ГД - 1. Порівняння у часовому інтервалі ГД - 2 і ГД - 3 дає розуміння того, що накладання джгутів на дві кінцівки у тварин з закритою травмою живота і масивною кровотечею поглиблює цитолітичні процеси, що відображається на активності АлАт і АсАТ.

Висновки. 1. В групах дослідження модельовані травми супроводжувались розвитком цитолітичних процесів, що мали тенденцію до розвитку в період ранніх проявів травматичної хвороби.

2. Ішемічно-реперфузійний синдром кінцівок значно потенціює розвиток системних змін при травмі органів черевної порожнини та гіповолемічному шоку, що відображалось значним зростанням показників АлАт та АсАТ в ГД - 3, які через 7 днів спостереження перевищували контрольні відповідно на 118,2 \% (p<0,001) та на 150,6 \% (p<0,001).

КлючОВІ слОВА: реперфузія; експеримент; джгут; цитолітичний синдром.

Вступ. В останні роки в Україні, як і у всьому світі, зростає кількість надзвичайних ситуацій як природного, так і техногенного характеру. Особливе місце серед надзвичайних ситуацій займають терористичні акти, навмисне та ненавмисне використання вибухових пристроїв у побуті тощо [1]. Особливістю таких ситуацій є виникнення високоенергетичних пошкоджень, які супроводжуються масивною кровотечою, пошкодженням значного масиву м'яких тканин [3]. Від клініцистів такі випадки потребують особливої уваги, оскільки до несприятливих факторів у таких постраждалих додається ішемічно-реперфузійний синдром кінцівок унаслідок накладання кровоспинних джгутів [4]. Його дія при поєднаній травмі фактично не вивчена.

Особливу роль при поєднаній травмі в контексті розвитку системних змін приділяють порушенню функції печінки. Це зумовлено тим, що одним із факторів поєднаної травми та ішемічно-реперфузійного синдрому $\epsilon$ токсемія, причому велика частина навантаження лягає на печінку, зокрема її детоксикаційну функцію $[2,5,6]$. Однак робіт, які б вивчали вплив ішемічно-реперфузійного синдрому на функцію печінки, зокрема розвитку цитолітичного синдрому при закритій травмі 
Огляди літератури, оригінальні дослідження, погляд на проблему, ювілеї

органів черевної порожнини, ускладненій гіповолемічним шоком, фактично немає.

Мета роботи - вивчити вплив ішемічно-реперфузійного синдрому на показники цитолітичного синдрому при травмі органів черевної порожнини, ускладненій гіповолемічним шоком, у ранньому післятравматичному періоді.

Матеріал і методи дослідження. Робочою гіпотезою експериментального дослідження $\epsilon$ припущення, що за умов безпечного використання кровоспинного джгута, з точки зору тривалості його застосування, реперфузія ішемізованих тканин призводить до надмірного утворення АФК, активації нейтрофілів і макрофагів, гіперпродукції токсичних метаболітів, сигнальних молекул цитокінового ряду та інших медіаторів запалення, які здійснюють системний вплив на організм з порушенням життєдіяльності внутрішніх органів при поєднаній травмі органів черевної порожнини на фоні гіповолемічного шоку.

Для реалізації поставленої мети на 80 нелінійних щурах-самцях масою 190-220 г з дотриманням правил «Європейської конвенції захисту хребетних тварин, яких використовують з експериментальною та іншою науковою метою» (European Convention, 1984) нами проведено експериментальне дослідження. Усіх тварин поділили на групи: контрольну і 3 дослідних (по 8 тварин у кожній групі). У тварин дослідних груп під тіопенталонатрієвим знеболюванням (40 мг·кг $)$ проксимально на ліві лапки накладали джгут на 120 хв. Як джгут застосовували еластичну смужку джгута «SWAT-T» (США) шириною 10 мм, що відповідає ширині джгута при накладанні на стегно дорослій людині. Джгут затягували відповідно до нанесеного на ньому індикатора ефективного тиску. Тварин дослідних груп виводили з експерименту в умовах тіопенталонатрієвого наркозу (60 мг·Кг $\left.{ }^{-1}\right)$ методом тотального кровопускання з серця через 1, 3 та 7 діб після репрерфузії. У контрольній групі (КГ) тварин тільки вводили в наркоз, застосовуючи еквівалентну дозу тіопенталу натрію, і в подальшому їх виводили з експерименту через 2 год.

У дослідних групах було змодельовано поєднану травму органів черевної порожнини в поєднанні з ішемічно-реперфузійним синдромом наступним чином: після проведення наркозу тіопенталом натрію тварині наносили дозований удар у ділянку черевної порожнини за допомогою спеціального пристрою; крововтрати в об'ємі від 20 до 22 \% об'єму циркулюючої крові досягали шляхом виконання операційного доступу і пересікання стегнових судин тварини протягом 1 хвилини (гостра крововтрата); ішемічно-реперфузійний синдром викликали шляхом накладання на обидві нижні кінцівки тварини кровоспинних джгутів терміном на дві години. Тварини дослідної групи були поділені на 3 підгрупи дослідження (ГД): ГД - 1 - моделювали реперфузійний синдром кінцівки без кровотечі та травми органів черевної порожнини; ГД - 2 - моделювали тяжку травму органів черевної порожнини та масивну крововтрату; ГД - 3 моделювали тяжку травму органів черевної порожнини, масивну крововтрату та реперфузійний синдром. Отримані дані порівнювали з даними КГ.

3 метою визначення змін цитолітичного синдрому визначали активність ферментів - маркерів цитолітичного синдрому - АлАТ і АсAT, уніфікованим методом для аналізатора біохімічного Humalyzer 2000, і виражали в одиницях на літр $\left(О д \cdot{ }^{-1}\right)$. Дослідження зазначених показників проводили в Центральній науковій лабораторії Тернопільського державного медичного університету імені І. Я. Горбачевського.

Отримані цифрові дані обробляли статистично. Вірогідність відмінностей між дослідними і контрольною групами оцінювали з використанням програми STATISTICA ("StatSoft, Inc.", США) на основі непараметричного критерію Манна-Уїтні.

Результати й обговорення. Як видно з даних, наведених в таблиці 1, після накладання джгутів на обидві задні кінцівки (ГД-1) активність АлАТ через 1 добу статистично достовірно підвищилася на $16,2 \%$, порівняно з контрольною групою ( $<<0,001)$. У подальшому показник продовжував зростати до 3 доби і перевищив рівень контрольної групи на 18,6 \%, до 7 доби показник дещо знизився, але все ще на 7,8 \% залишався вищим, ніж у контрольній групі. У ГД - 2, у якій була змодельована закрита травма живота з масивною зовнішньою кровотечею, активність АлАТ через 1 добу статистично достовірно підвищилася на 19,1\%, порівняно з групою тварин, що не мали травм $(p<0,01)$, і продовжила наростати на 3 і 7 доби на 43,3 \% і 45,2 \% відповідно, порівняно з контрольною групою ( $<<0,001)$. Найбільше зростання активності АлАТ сироватки крові відбулося в ГД - 3. У цій групі рівень показника зріс на 37,1 \% вже протягом 1 доби. На 3 добу показник зріс на 84,4 \%, а на 7 добу - на 118,2 \% перевищував рівень контрольної групи. Вказані дані ДГ- 3 мають сильну статистичну достовірність ( $<<0,001)$. Таким чином, наростання активності АлАТ протягом контрольних точок відображає посилення цитолітичного синдрому, якщо закрита травма черевної порожнини з масивною крововтратою поєднується з накладанням джгутів на обидві задні кінцівки.

Порівнюючи показники дослідних груп між собою ми з'ясували, що через 1 добу після нанесення травми активність АлАТ сироватки крові наростала відповідно до збільшення пошкоджень. Через 3 і 7 діб вона ставала істотно вищою 
Огляди літератури, оригінальні дослідження, погляд на проблему, ювілеї

Таблиця 1. Активність АлАТ сироватки крові (Од·л-1) у групах дослідження, Me (LQ;UQ) - медіана (нижній і верхній квартилі)

\begin{tabular}{|c|c|c|c|c|}
\hline \multirow{2}{*}{ Групи дослідження } & \multirow{2}{*}{ Контроль } & \multicolumn{3}{|c|}{ Термін дослідження } \\
\hline & & 1 доба & 3 доба & 7 доба \\
\hline гД-1 & \multirow{3}{*}{$\begin{array}{c}185,1 \\
(182,2 ; 190,8) \\
(n=8)\end{array}$} & $\begin{array}{c}215,1^{*} \\
(210,3 ; 219,3)(n=8)\end{array}$ & $\begin{array}{c}219,5^{*} \\
(215,3 ; 222,9)(n=8)\end{array}$ & $\begin{array}{c}199,5^{*}(194,7 ; 207,6) \\
(n=8)\end{array}$ \\
\hline ГД-2 & & $\begin{array}{c}220,3^{*} \\
(205,8 ; 228,9)(n=8)\end{array}$ & $\begin{array}{c}265,2^{*} \\
(254,8 ; 287,7)(n=8)\end{array}$ & $\begin{array}{c}268,7^{*} \\
(261,7 ; 305,9)(n=8)\end{array}$ \\
\hline ГД-3 & & $\begin{array}{c}253,6^{*} \\
(239,5 ; 266,0)(n=8)\end{array}$ & $\begin{array}{c}341,4^{*} \\
(321,1 ; 371,7)(n=8)\end{array}$ & $\begin{array}{c}403,9^{*} \\
(392,5 ; 427,1)(n=8)\end{array}$ \\
\hline \multicolumn{2}{|c|}{$\mathrm{P}_{1-2}$} & $>0,05$ & $<0,001$ & $<0,001$ \\
\hline \multicolumn{2}{|c|}{$P_{1-3}$} & $<0,001$ & $<0,001$ & $<0,001$ \\
\hline \multicolumn{2}{|c|}{$P_{2-3}$} & $<0,01$ & $<0,001$ & $<0,001$ \\
\hline
\end{tabular}

Примітки: тут і в інших таблицях:

1. * Достовірність відмінностей стосовно контрольної групи: * $-p<0,05 ; * *-p<0,01 ; * * *-p<0,01$.

2. $\mathrm{p}_{1-2}-$ достовірність відмінностей показника між групами тварин ГД-1 та ГД-2; $\mathrm{p}_{1-3}-$ між ГД-1 та ГД - 3; $\mathrm{p}_{2-3}-$ між ГД-2 та ГД-3.

на тлі травми живота і масивної крововтрати, і ще більшою - при поєднанні вказаних пошкоджень 3 накладанням джгутів на кінцівки, порівняно 3 контрольною групою. В ГД - 1 на 7 добу відмічається поступове зниження рівня активності по- казника відносно 1 і 3 діб, з зареєстрованим максимумом показника на 3 добу (рис. 1). Всі дані, отримані на 3 і 7 добу, демонструють сильну статистичну достовірність $\left(\mathrm{p}_{1-2}<0,001, \mathrm{p}_{1-3}<0,001\right.$, $\left.\mathrm{p}_{2-3}<0,001\right)$.

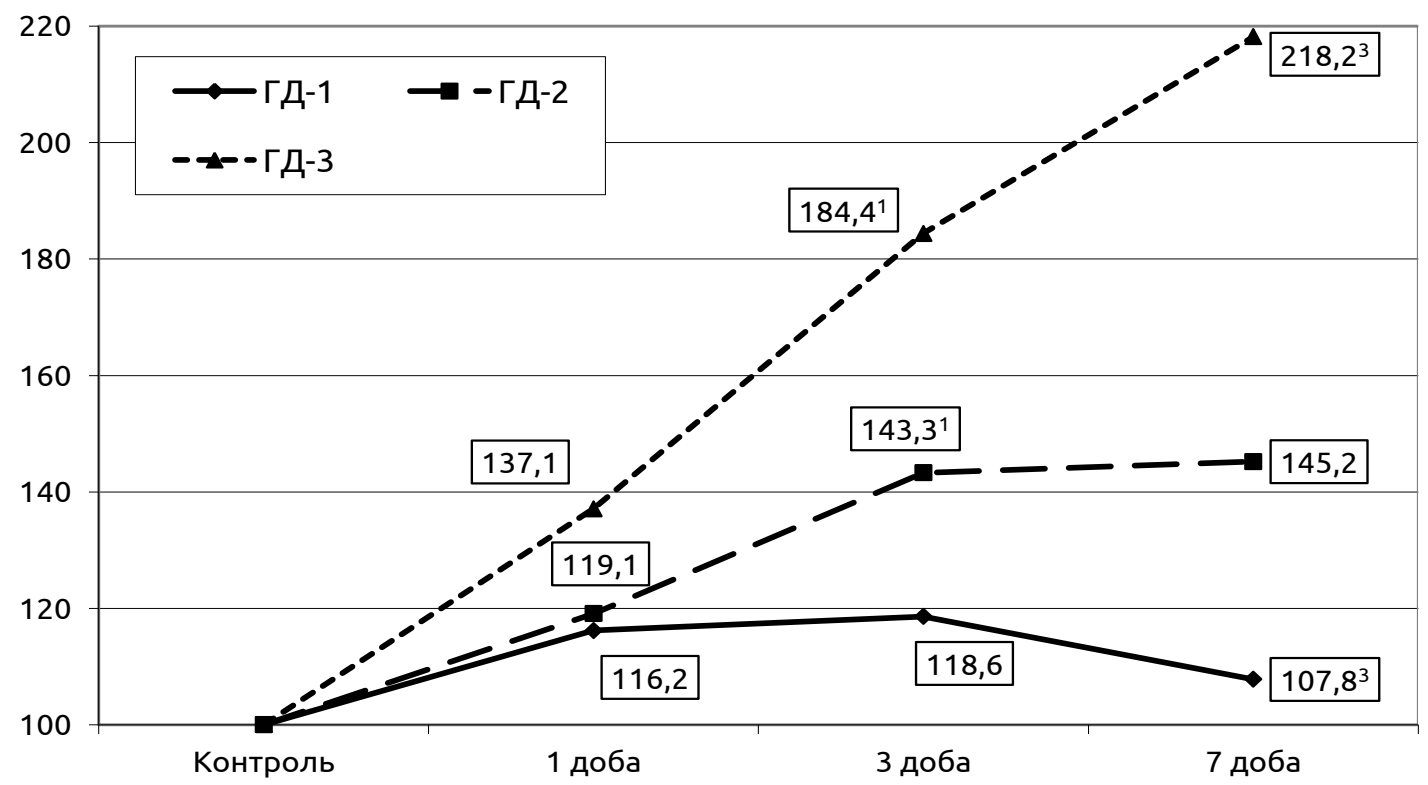

Рис. 1. Динаміка активності АлАТ сироватки крові (у відсотках до рівня контрольної групи) у дослідних групах. (Примітка. Тут і на інших рисунках: 1,3 - відмінності стосовно 1 і 3 діб спостереження статистично достовірні, р<0,05).

Активність АсАТ сироватки крові (табл. 2, рис. 2) за умов модельованих травм теж була статистично достовірно більшою від контролю в усі терміни спостереження. Після накладання джгутів без нанесення додаткових травм через 1 добу показник перевищував рівень контрольної групи на 21,8 \%, через 3 доби - на 44,7\%, через 7 діб - на $38,6 \%$. В ГД - 2 він зростав на 37,1, 74,1 і 81,6 \% і в ГД - 3 - на 62,1, 123,3 та 150,6 \% ( $p<0,001)$, відповідно до доби спостереження.
Порівнюючи показники дослідних груп між собою ми з'ясували, що вже через 1 добу посттравматичного періоду активність АсАТ сироватки крові була істотно вищою після абдомінальної травми на фоні масивної кровотечі, ніж при джгутуванні обох задніх кінцівок, і ще вищою при поєднанні травми з джгутуванням (на $12,5 \%, \mathrm{p}_{1-2}<0,05$ і на $33 \%$, $\mathrm{P}_{1-3}<0,001$ відповідно). Тенденція до зростання показника від ГД - 1 до ГД - 3 відповідно продовжується і на $3\left(p_{1-2}<0,01, p_{1-3}<0,001, p_{2-3}<0,001\right)$ та 7 доби 
Огляди літератури, оригінальні дослідження, погляд на проблему, ювілеї

Таблиця 2. Активність АсАТ сироватки крові (Од·л-1) у групах дослідження, Me (LQ;UQ) - медіана (нижній і верхній квартилі)

\begin{tabular}{|c|c|c|c|c|}
\hline \multirow{2}{*}{ Групи дослідження } & \multirow{2}{*}{ Контроль } & \multicolumn{3}{|c|}{ Термін дослідження } \\
\hline & & 1 доба & 3 доба & 7 доба \\
\hline гд - 1 & \multirow{3}{*}{$\begin{array}{c}110,2 \\
(107,2 ; 114,9) \\
(n=8)\end{array}$} & $\begin{array}{c}134,2^{*} \\
(123,6 ; 138,4)(n=8)\end{array}$ & $\begin{array}{c}159,5^{*} \\
(151,2 ; 166,6)(n=8)\end{array}$ & $\begin{array}{c}152,7^{*}(146,8 ; 164,3) \\
(n=8)\end{array}$ \\
\hline ГД-2 & & $\begin{array}{c}151,0^{*} \\
(145,9 ; 155,4)(n=8)\end{array}$ & $\begin{array}{c}191,9^{*} \\
(164,4 ; 197,6)(n=8)\end{array}$ & $\begin{array}{c}200,1^{*} \\
(196,2 ; 202,9)(n=8)\end{array}$ \\
\hline ГД- 3 & & $\begin{array}{c}178,6^{*} \\
(175,3 ; 197,9)(n=8)\end{array}$ & $\begin{array}{c}246,1^{*} \\
(219,7 ; 252,8)(n=8)\end{array}$ & $\begin{array}{c}276,1^{*} \\
(225,6 ; 289,2)(n=8)\end{array}$ \\
\hline$P_{1-2}$ & & $<0,05$ & $<0,01$ & $<0,001$ \\
\hline$P_{1-3}$ & & $<0,001$ & $<0,001$ & $<0,001$ \\
\hline$P_{2-3}$ & & $<0,001$ & $<0,001$ & $<0,001$ \\
\hline
\end{tabular}

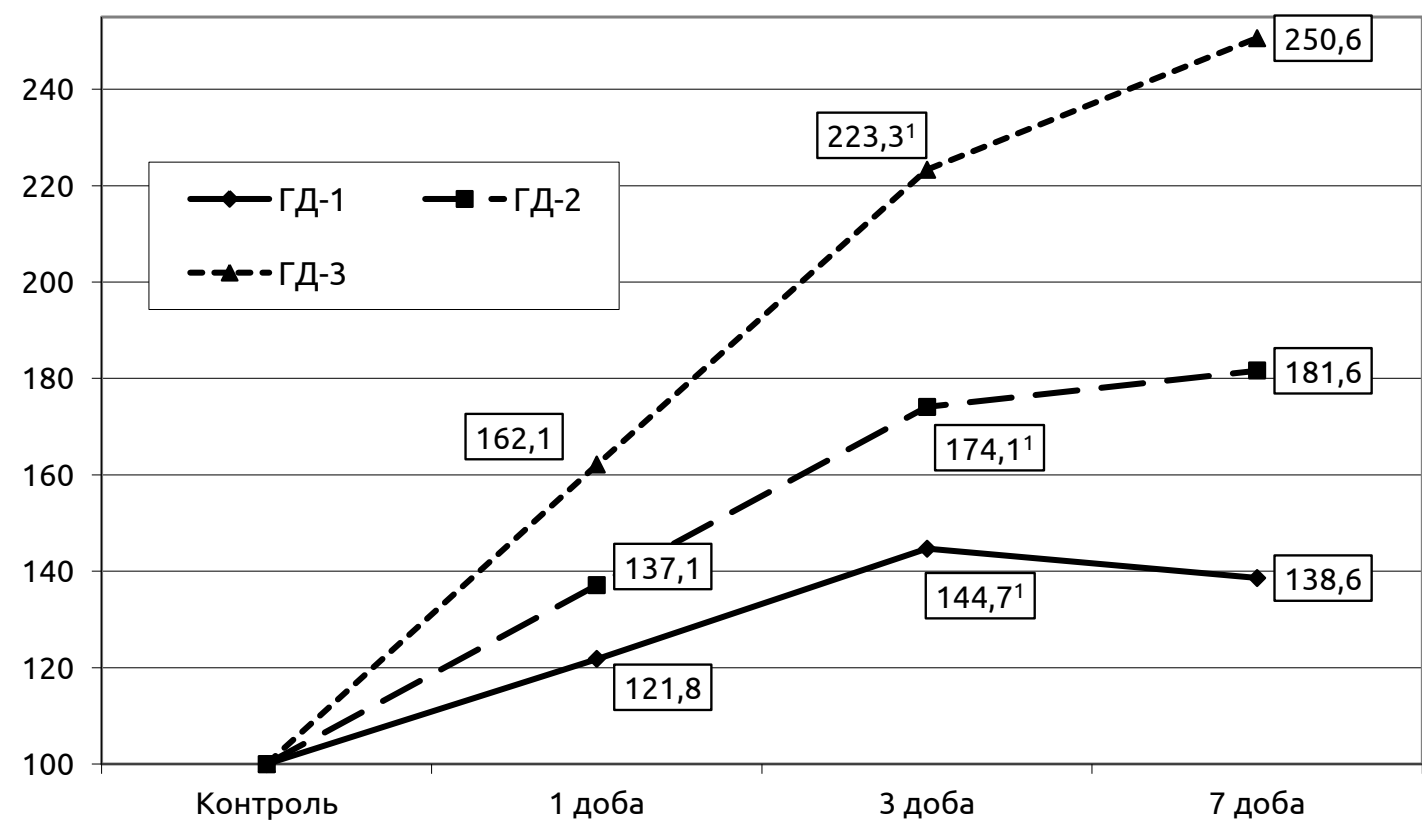

Рис. 2. Динаміка активності АсАТ сироватки крові (у відсотках до рівня контрольної групи) у дослідних групах.

$\left(p_{1-2}<0,001, p_{1-3}<0,001, p_{2-3}<0,001\right)$. Статистична достовірність вказана відповідно.

Таким чином, за умов модельованих травм, незважаючи на їх походження, розвиваються цитолітичні процеси, які мають системний характер. Уже через 1 добу посттравматичного періоду зростає активність АлАТ та АсАТ, і це зростання чітко відмічається не лише в ГД- 2 і ГД - 3, а і в ГД - 1 . У подальшому, до 3 доби, процес деструкції клітинних мембран поглиблюється, що проявляється істотним збільшенням активності АлАТ і АсАТ сироватки крові і продовжує поглиблення до 7 доби. Тенденція до зниження рівнів АсАТ і АлАТ спостерігається лише на 7 добу у ГД - 1. Порівняння у часовому інтервалі ГД - 2 і ГД - 3 дає розуміння того, що накладання джгутів на дві кінцівки у тварин з закритою травмою живота і масивною кровотечею поглиблює цитолітичні процеси, що відображається на активності АлАт і АсАТ.
Висновки. 1. У групах дослідження модельовані травми супроводжувались розвитком цитолітичних процесів, що мали тенденцію до розвитку в період ранніх проявів травматичної хвороби.

2. Ішемічно-реперфузійний синдром кінцівок значно потенціює розвиток системних змін при травмі органів черевної порожнини та гіповолемічному шоку, що відображалось значним зростанням показників АлАт та АсАТ в ГД - 3, які через 7 днів спостереження перевищували контрольні відповідно на 118,2 \% ( $p<0,001)$ та на 150,6 \% $(p<0,001)$.

Перспективи подальших досліджень. У перспективі передбачається більш детальне вивчення впливу ішемічно-реперфузійного синдрому на функцію печінки та розробка на основі цього оптимальних шляхів корекції. 
Огляди літератури, оригінальні дослідження, погляд на проблему, ювілеї

\section{ЛІТЕРАТУРА}

1. Emergency tourniquets for civilians: can military lessons in extremity hemorrhage be translated? / G. Ode, J. Studnek, R. Seymour [et al.] // J. Trauma Acute Care Surg. - 2015. - Vol. 79- P. 586-591.

2. Kafadar H. Comparison of internal organ injuries by blunt abdominal trauma in rats with empty or full stomach / H. Kafadar, S. Kafadar, M. Tokdemir // Ulus Travma Acil Cerrahi Derg. - 2014. - Vol. 20 (6). - P. 395-400.

3. Singh K. J. Abdominal trauma in combat / K. J. Singh, A. Galagali//Med. J. Armed Forces India.-2010.-Vol. 66 (4).P. 333-337.

\section{REFERENCES}

1. Ode, G., Studnek, J., Seymour, R., Bosse, M.J. \& Hsu, J.R. (2015). Emergency tourniquets for civilians: can military lessons in extremity hemorrhage be translated? J. Trauma Acute Care Surg., 79, 586-591.

2. Kafadar, H., Kafadar, S. \& Tokdemir, M. (2014). Comparison of internal organ injuries by blunt abdominal trauma in rats with empty or full stomach. Ulus Travma Acil Cerrahi Derg., 20(6), 395-400.

3. Singh, K.J. \& Galagali, A. (2010). Abdominal Trauma in Combat. Med. J. Armed Forces India, 66(4), 333-337.

4. Stockinger, Z.T., Turner, C.A. \& Gurney, J.M. (2018). Abdominal trauma surgery during recent US combat
4. Stockinger Z. T. Abdominal trauma surgery during recent US combat operations from 2002 to 2016 / Z. T. Stockinger, C. A. Turner, J. M. Gurney // Journal of Trauma and Acute Care Surgery. - 2018. - Vol. 85. - P. 122-128.

5. Tourniquet use for civilian extremity trauma. / K. Inaba, S. Siboni, S. Resnick [et al.] // J. Trauma Acute Care Surg. 2015 - 79. - P. 232-237.

6. The effect of permissive hypotension in combined traumatic brain injury and blunt abdominal trauma: an experimental study in swines / T. Vrettos, E. Poimenidi, P. Athanasopoulos [et al.] // Eur. Rev. Med. Pharmacol. Sci. - 2016. Vol. 20 (4). - P. 620-630. operations from 2002 to 2016. Journal of Trauma and Acute Care Surgery, 85, 122-128.

5. Inaba, K., Siboni, S., Resnick, S., Wong, Zh.J., Haltmeier, T., Benjamin, E. \& Demetriades, D. (2015). Tourniquet use for civilian extremity trauma. J. Trauma Acute Care Surg., 79, 232-237.

6. Vrettos, T., Poimenidi, E., Athanasopoulos, P., Balasis, S., Karagiorgos, N., Siklis, ... Fligkou, F. (2016). The effect of permissive hypotension in combined traumatic brain injury and blunt abdominal trauma: an experimental study in swines. Eur. Rev. Med. Pharmacol. Sci., 20(4), 620630.

\section{ВЛИЯНИЕ ИШЕМИЧЕСКИ-РЕПЕРФУЗИОННОГО СИНДРОМА КОНЕЧНОСТЕЙ НА ОТКЛОНЕНИЯ ПОКАЗАТЕЛЕЙ ЦИТОЛИТИЧЕСКОГО СИНДРОМА}

○И. В. Кузьминский

\section{Государственное учреждение «Украинский научно-практический центр экстренной медицинской помощи и медицины катастроф Мз Украины», Киев}

PEЗЮМЕ. В последние годы в Украине, как и во всем мире, растет число чрезвычайных ситуаций, как природного, так и техногенного характера. Особое место среди чрезвычайных ситуаций занимают террористические акты, преднамеренное и непреднамеренное использование взрывных устройств в быту. Особенностью таких ситуаций является возникновение высокоэнергетических повреждений, сопровождающихся массивным кровотечением, повреждением значительного массива мягких тканей. От клиницистов такие случаи требуют особого внимания, поскольку к неблагоприятным факторам у таких пострадавших добавляется ишемически-реперфузионный синдром конечностей вследствие наложения кровоостанавливающих жгутов. Его действие фактически не изучено при сочетанной травме.

Цель работы - изучить влияние ишемически-реперфузионного синдрома на показатели цитолитического синдрома при травме органов брюшной полости, осложненной гиповолемическим шоком, в раннем посттравматическом периоде.

Материал и методы. В эксперименте использовали 80 половозрелых белых крыс-самцов линии Wistar массой 190-220 г, которые находились на стандартном рационе вивария.

Животных поделили на контрольную и 3 опытных группы (по 8 животных в каждой группе). У животных первой опытной группы под тиопенталонатриевым наркозом (40 $\left.\mathrm{Mr} \cdot \mathrm{k}^{-1}\right)$ проксимально на нижние лапки накладывали кровоостанавливающий жгут сроком на 120 мин., что вызвало развитие ишемически-реперфузионного синдрома. Во второй исследовательской группе моделировали закрытую травму органов брюшной полости с помощью нанесения двух дозированных ударов в область брюшной полости; путем пересечения бедренных сосудов и кровопускания от 20 до 22 \% объема циркулирующей крови в группе моделировали гиповолемический шок. В третьей группе исследования сочетали повреждения первых двух групп. Животных контрольной группы только вводили в наркоз, травм им не моделировали.

С целью определения изменений цитолитического синдрома определяли активность ферментов - маркеров цитолитического синдрома АлАТ и АсАТ унифицированным методом. 
Огляди літератури, оригінальні дослідження, погляд на проблему, ювілеї

Животных опытных групп выводили из эксперимента в условиях тиопенталонатриевого наркоза методом тотального кровопускания из сердца.

Результаты. Наши исследования показали, что в условиях смоделированных травм, несмотря на их тип, развиваются цитолитические процессы, которые носят системный характер. Так, уже через 1 сутки посттравматического периода возрастает активность АлАТ и АсАТ, которая четко отмечается не только в ГД-2 и ГД-3, но и в ГД-1. В дальнейшем до 3 суток процесс деструкции клеточных мембран углубляется, что проявляется существенным увеличением активности АлАТ и АсАТ сыворотки крови, и продолжает углублятся до 7 суток. Тенденция к снижению уровней АсАТ и АлАТ наблюдается лишь на 7 сутки в ГД-1. Сравнение во временном интервале ГД-2 и ГД-3 дает понимание того, что наложение жгутов на две конечности у животных с закрытой травмой живота и массивным кровотечением углубляет цитолитические процессы, отражается на активности АлАТ и АсАТ.

Выводы. 1. В группах исследования моделируемые травмы сопровождались развитием цитологических процессов, имели тенденцию к развитию в период ранних проявлений травматической болезни.

2. Ишемически-реперфузионный синдром конечностей значительно потенцирует развитие системных изменений при травме органов брюшной полости и гиповолемическом шоке, что отображалось значительным ростом показателей АлАТ и АсАТ в ГД - 3, которые через 7 дней наблюдения превышали контрольные соответственно на $118,2 \%(p<0,001)$ и на $150,6 \%(p<0,001)$.

кЛючЕВЫЕ СЛОВА: реперфузия; експеримент; жгут; цитолитический синдром.

\title{
INFLUENCE OF ISCHEMIC-REPERFUSION SYNDROME OF EXTREMITIES FOR CYTOLYTIC SYNDROME
}

\author{
@I. V. Kuzminskyi \\ Ukrainian Scientific and Practical Center of Emergency and Disaster Medicine, Kyiv
}

SYMMARY. Introduction. In recent years in Ukraine, as in the whole world, the number of emergencies, both natural and man-made, has increased. A special place among emergencies is occupied by terrorist acts, the deliberate and unintentional use of explosive devices in everyday life. The features of such situations are the emergence of high-energy injuries, which are accompanied by massive bleeding, damage to a large array of soft tissues. For clinicians, such cases require special attention, because the adverse factors in such patients are added ischemic-reperfusion syndrome of the extremities due to overlaying hemostatic harnesses. His action has not been actually studied in conjunction with a trauma.

The aim of the work - to study the effect of ischemic-reperfusion syndrome on the indicators of the cytolytic syndrome in the trauma of the abdominal cavity complicated by hypovolemic shock in the early post-traumatic period.

Material and Methods. In the experiment, 80 sexually mature white male rats, Wistar weighing 190-220 g, were found on a standard vivarium diet.

Animals were divided into control and 3 experimental groups ( 8 animals per group). In the animals of the first experimental group under the thiopental-sodium enzymes $(40 \mathrm{mg} \cdot \mathrm{kg}-1)$ proximal to the lower paws imposed a hemostatic tourniquet for 120 minutes, which caused the development of ischemic-reperfusion syndrome. In the second experimental group, they simulated a closed trauma of the abdominal cavity by applying two dose injections to the region of the abdominal cavity; Hypovolemic shock was modeled in a group by crossing the femoral vessels and bloodletting from 20 to $22 \%$ of the volume of circulating blood. In the third group of studies, the damage was combined with the first two groups. Animals of the control group were injected into the anesthesia without any injury.

In order to determine the changes in the cytolytic syndrome, the activity of the enzymes markers of the cytolytic syndrome ALT and AST was determined by a unified method.

Animals of experimental groups were extracted from the experiment under conditions of thiopental sodium anesthesia by the method of total blood-flow from the heart.

Results and Discussion. Our studies have found that in the conditions of simulated injuries, despite their type, develop cytolytic processes that are systemic in nature. So, after 1 day of post-traumatic period the activity of ALT and AST increases, which is clearly marked not only in RG-2 and RG-3, but also in RG-1. In the future, before 3 days, the process of destruction of cell membranes deepens, which manifests a significant increase in the activity of ALT and AST serum and continues to deepen to 7 days. The tendency to decrease the levels of ALT and AST is observed only for 7 days in RG-1. The comparison in the time interval of RG-2 and RG-3 gives an understanding that the imposition of two-legged harness in animals with closed abdominal trauma and massive bleeding deepens the cytolytic processes, which affects the activity of ALT and AST.

Conclussions. 1. In the study groups simulated traumas were accompanied by the development of cytolytic processes that tended to develop during the early manifestations of traumatic illness.

2. Ischemic-reperfusion syndrome of the extremities potentiates the development of systemic changes in the trauma of the abdominal cavity and hypovolemic shock, which was revealed by a significant increase in AlAt and AsAT in GD-3, which after 7 days of observation exceeded controls by $118.2 \%(p<0.001)$ and by $150.6 \%(p<0.001)$.

KEY WORDS: reperfusion; experiment; tourniquet; cytolytic syndrome. 